\title{
TRADISI PERANG SUCI DALAM PERJANJIAN LAMA
}

\author{
Robi Prianto
}

\begin{abstract}
The tradition of holy war in the Old Testament does not appear out of nowhere, but through a long process in the cultural history of the nation of Israel. The tradition of Holy War in the Old Testament coincided with the emergence of Israeli culture itself. Holy war in Israel trust is a form of sacred covenant between the people of Israel with God. Where the Israelites made a covenant with God in heaven to give the victory to them from the attacks of his enemies. In the development of holy war into a sacred institution, cult and strong in the belief of the nation of Israel.
\end{abstract}

\section{Abstrak}

Tradisi perang suci dalam Perjanjian Lama tidak muncul begitu saja, tetapi melalui proses yang panjang dalam sejarah budaya bangsa Israel. Tradisi Perang Suci dalam Perjanjian Lama terjadi bersamaan dengan munculnya kebudayaan Israel itu sendiri. Perang suci dalam kepercayaan Israel merupakan suatu bentuk perjanjian yang sakral antara umat Israel dengan Allah. Di mana bangsa Israel mengikat perjanjian dengan Allah di surga untuk memberikan kemenangan kepada mereka dari serangan musuhmusuhnya. Dalam perkembangannya perang suci menjadi suatu lembaga yang sakral, kultus dan kuat dalam kepercayaan bangsa Israel.

Key Words: The tradition, holy war, a covenant, Old Testament 


\section{PENDAHULUAN}

Kata perang bukanlah merupakan suatu hal yang asing didengar oleh masyarakat dunia, terlebih khusus di Indonesia. Akhir-akhir ini, hampir semua media elektronik maupun cetak di Indonesia sering menayangkan dan memberitakan mengenai perang saudara yang terjadi di Suriah. Begitu pula dengan yang terjadi di beberapa daerah Nusantara beberapa tahun yang lalu juga mengalami hal serupa, contohnya; seperti yang terjadi di Poso dan Ambon, di mana institusi agama dijadikan instrumen dalam membenarkan tindakan perang yang dilakukan oleh kelompok-kelompok tertentu. Perang digunakan untuk membela nama Tuhan, padahal jika diteliti dengan seksama dan lebih lanjut, kepentingan pribadi atau ego manusialah yang menjadi alasan terjadinya perang, karena setiap orang merasa dirinya yang paling benar.

Isu perang atas nama Tuhan selalu menjadi topik yang hangat mulai dari jaman Perjanjian Lama hingga saat ini. Setiap pengikut suatu agama tertentu sangat bersemangat jika membahas perang demi membela agamanya. Bahkan bangsa Israel pun menjadikan perang atas nama Allah sebagai suatu hal yang kultus dan sakral, yang dimulai dengan memberikan kurban bakaran kepada Allah sebelum mereka pergi berperang, dengan tujuan Allah memberikan kemenangan bagi mereka (Hak 6:20, 26).

Berdasarkan latar belakang masalah di atas, maka penulis tertarik untuk menulis tulisan dengan judul "Tradisi Perang Suci dalam Perjanjian Lama”.

Bertolak dari Tradisi Perang Suci dalam Perjanjian Lama, maka ada beberapa pertanyaan penting dalam kaitannya dengan kehidupan 
orang percaya saat ini. Pertama, bagaimanakah awal munculnya tradisi Perang Suci dalam Perjanjian Lama? Kedua, apakah makna Perang Suci dalam Perjanjian Lama bagi umat Israel? Ketiga, adakah implikasi dari perang suci dalam Perjanjian Lama bagi kehidupan iman orang percaya saat ini?

Jadi tulisan ini penting, pertama ingin menjelaskan awal munculnya tradisi Perang Suci dalam Perjanjian Lama. Kedua, ingin menjelaskan makna Perang Suci dalam Perjanjian Lama bagi umat Israel. Ketiga, ingin memaparkan implikasi dari perang suci dalam Perjanjian Lama bagi kehidupan iman orang percaya saat ini.

\section{Awal Munculnya Tradisi Perang Suci dalam Perjanjian Lama}

Di dalam beberapa bagian Alkitab kata perang dapat dengan mudah dijumpai, khususnya di dalam Perjanjian Lama (PL). Kata perang dalam bahasa Ibrani memakai kata milkhamah. Kata milkhamah sendiri berasal dari akar kata lakham (berperang). Kata milkhamahmuncul lebih dari 300 kali mulai dari kanon Torah (Kej 14:2) sampai dengan Ketubim (Dan 9:26). ${ }^{1}$

Dalam membahas munculnya tradisi perang suci, maka Kitab Ulangan adalah sumber terlengkap atau terkaya di dalam Perjanjian Lama mengenai konsep dan kebiasaan dari perang suci. Kitab Ulangan tidak hanya berisi serangkaian perintah normatif secara rinci dan resep tentang perilaku dan kebiasaan di kamp, sebelum pertempuran, dan sebagainya, tetapi juga sangat kontras dengan

${ }^{1}$ Yonky Karman, Perang Dalam Perjanjian Lama: Problem Reinterpretasi, http://www.alkitab.or.id/biblika/Yonky4.htm(Diunduh pada tanggal 13 Januari 2015). 
hukum kekudusan. Dari pasal pertama sampai dengan terakhir, kitab Ulangan secara terbuka membahas ideologi dari perang, asal-usul dan isi teologis dari perang itu sendiri. Semua alamat dan hukum dalam Ulangan diberikan kepada Israel secara terus-menerus dengan tujuan mereka sadar siapa dirinya, dan musuh-musuhnya.

Ideologi perang muncul melalui editing Deuteronomistis dari banyak buku bersejarah bahkan hampir seluruh Perjanjian Lama. Hal ini terjadi, karena penulis Kitab Ulangan menarik ke dalam tubuhnya semua jenis teks bahan hukum yang berasal dari zaman jauh lebih tua, sehingga sebagai akibatnya, sesekali muncul ketegangan antara materi hukum yang lebih tua dan konsepsi serta tujuan dari penulis sendiri.

Bentuk kritis analisis belum sepenuhnya dilakukan dalam Ulangan karena pidato parenetic orang Lewi dibingkai melalui pembacaan hukum sebagai pidato yang memperingatkan Israel dan berfungsi sebagai janji-janji berkat. Teks-teks yang dibingkai itu hanya semacam pemberitaan hukum, namun ada yang hilang dalam Ulangan 7:16-26 yaitu, kiasan mengenai keinginan Yahweh dalam hal keadilan atau hukum, "yang kuperintahkan kepadamu pada hari ini". Dari hal tersebut dapat terlihat mengenai prinsip-prinsip dari perang suci. Dimana Allah memberikan teror kepada musuh-musuh Israel. Jika Sitz im Leben bagian parenetic ini dipertanyakan, maka semua pidato adalah [ditujukan kepada orang] dalam perang suci. Namun, hal itu tidak mungkin sudah diucapkan dengan cara tersebut pada zaman para hakim. ${ }^{2}$

${ }^{2}$ Gerhard von Rad, Holy War in Ancient Israel (Eugene: Wipf and Stock Publishers, 2000) 115-121. 
Pada awalnya sikap Israel terhadap peperangan sangatlah kompleks dan saling bertentangan. Ada tujuh bentuk peperangan dalam Alkitab khususnya dalam Perjanjian Lama, yaitu ${ }^{3}$

1. Bentuk perang yang pertama, yaitu perang yang menuntut pembinasaan total dari musuhnya, tanpa terkecuali (U1 2:34-35; Yos 6:17-21; 8:2, 24-25). Dalam perspektif ini, kematian musuh bukanlah merupakan persoalan pembalasan yang adil, tetapi untuk menyenangkan Allah dengan pengorbanan manusia.

2. Bentuk yang kedua, yaitu perang yang menghendaki pemusnahan musuh seluruhnya sebagai orang-orang berdosa yang dihukum oleh keadilan ilahi (Ul 13:12-18; 20:10-18). Dalam perspektif ini, pemusnahan merupakan tuntutan keadilan.

3. Bentuk perang yang ketiga, yaitu tradisi Priestly, yang menuntut dengan tegas pemusnahan musuh karena alasan ketidaksucian mereka (Bil 31).

4. Bentuk perang yang keempat adalah tradisi puitis yang mengagungkan perang sebagai sesuatu yang indah dan mulia, memuji kepahlawanan dan membesarkan hati para prajurit (1 Sam 17:1-54; 2 Sam 2:12-16; 2 Raj 6:22-23; 2 Taw 28). Dalam perspektif ini, perang adalah pertandingan yang harus dimainkan sesuai dengan aturan untuk memenangkan kehormatan.

5. Bentuk perang yang kelima adalah peperangan difokuskan kepada pihak yang lemah, yang melakukan penipuan, dengan menggunakan alasan dan kebohongan untuk memperoleh kemenangan dalam melawan musuh yang lebih kuat (Kej 34; Hak 3:12-20; Est 8-9).

3 Leo D. Lefebure, Penyataan Allah, Agama, dan kekerasan (Jakarta: BPK. Gunung Mulia, 2006) 90-92. 
6. Bentuk perang yang keenam adalah ideologi asas manfaat yang memandang bahwa semua alat dibutuhkan dan dibenarkan dalam peperangan (Hak 9:45-47; 2 Sam 5:6-8).

7. Bentuk perang yang terakhir, yaitu perang dengan ideologi non-partisipasi yang dilakukan oleh orang Israel sendiri (Kel 14-15). Umat Israel berdiri di pinggir arena, ketika Allah berperang bagi mereka, sehingga Allahlah yang memiliki semua kebesaran. Dalam bentuk perang ini, umat Israel hanya bersandar pada pertolongan Allah, seperti dalam kemenangan prototip Allah atas tentara Mesir di Laut Merah.

Menurut Walter Kaiser dan Henrik van Oyen, bangsa Israel kuno pada dasarnya merupakan bangsa yang cinta damai, meskipun bukti kekerasan banyak dijumpai di dalam tradisi mereka. Sedangkan menurut Johannes Hempel dalam etika Perjanjian Lama, bangsa Israel merupakan bangsa yang sangat memegang teguh pada perjanjian, sejarah, dan Yabweh sebagai Allah yang mereka sembah. Isu perang dalam Perjanjian Lama muncul dalam konteks membahas hubungan dengan orang asing atau dalam hal bentuk balas dendam atas perjanjian yang rusak. ${ }^{4}$

Gerhard von Rad menggambarkan perang sebagai perintah Allah, dimana Allah sendiri pemimpin perang dan dalam Kitab Suci Ibrani hal itu disebut sebagai "Perang Suci" dan "lembaga kultus". Disebut kultus karena semua emas dan perak, manusia dan hewan menjadi persembahan bagi Allah (Yos 6:18-19). Tipologi perang suci menurut Von Rad termasuk di dalamnya adalah motif peniupan terompet, penyucian para tentara, proklamasi kemenangan janji oleh

${ }^{4}$ Susan Niditch, War In The Hebrew Bible, A Study In The Ethics Of Violence. (New York: Oxford University Press, 1993) 7. 
Tuhan, kepemimpinan Allah, kebutuhan total kepercayaan oleh Israel, hilangnya keberanian musuh karena "teror ilahi", diberlakukannya berem atau larangan setelah kemenangan, dan pemberhentian pasukan. Konsep perang suci itu merupakan suatu wujud nyata dari herem (suatu ritual khusus), dimana bangsa Israel mengikat perjanjian dengan Allah, sehingga Allah sendiri yang bertindak di dalam perang, sehingga bangsa Israel memperoleh kemenangan tanpa melakukan tindakan fisik. Sebab Allah sendiri yang memberikan terror atau ketakutan kepada musuh-musuh Israel. Alasan inilah (intervensi Allah) yang membuat bangsa Israel memandang perang itu sebagai suatu ritual suci, dimana setiap pertempuran selalu dibuka dengan tiupan terompet atau sangkakala (Hak 7:20; Yos 6:5; 1 Sam 17:20, 52; 2 Taw 20:21-22) yang menandakan bahwa Allah hadir atas Isarel. Perang Suci pada awalnya merupakan suatu lembaga sakral yang terbentuk sebagai perjanjian antara Israel dengan Allah dengan tujuan untuk menjaga iman mereka dari gangguan pihak luar. ${ }^{5}$

Bagi bangsa Israel semua segi kehidupan mereka, terjalin dengan Allah. Termasuk dalam hal peperangan. Di dalam Perjanjian Lama, banyak ayat yang mengindikasikan Allah terlibat dalam peperangan yang dilakukan oleh bangsa Israel, diantaranya yaitu Allah sebagai pahlawan perang (Kel 15:3; Yes 42:13), Tuhan mengepalai bala tentara (2 Taw 13:12). Allah menyuruh umat-Nya keluar untuk berperang (2 Taw 6:34). Allah melakukan penghadangan (2 Taw 20:22), dan Allah mengajar pemazmur untuk bertempur (Mzm 144:1). Allah mengambil alih pertempuran, sementara tentara Israel tinggal diam saja (2 Taw 20:17). Tanda

${ }^{5}$ von Rad, Holy War in Ancient Israel, 48-51. 
bahwa Allah hadir dan menyertai bangsa Israel adalah adanya tabut perjanjian dalam kemah suci mereka. Oleh sebab itu, peperangan harus berhasil (1 Taw 5:22), karena Allah sendiri akan menyerahkan musuh ke dalam tangan umat-Nya (Ul 20:13), dan terkadang Allah memakai kekuatan alamiah untuk tujuan tersebut (Hak 5:4, 5). Oleh karena itu, perang dan segala persiapannya dianggap kudus (qiddesy milkhama), karena didahului dengan ritual penyerahan kurban bakaran (Hak 6:20, 26). ${ }^{6}$ Termasuk barang-barang hasil jarahan dalam setiap pertempuran yang dilakukan tidak boleh diambil, karena barang-barang itu sudah dikhususkan untuk Allah (harus dihancurkan tanpa terkecuali).

Teks-teks Alkitab yang mengacu pada penghancuran atas barang-barang hasil perang bagi Allah memakai kata "Herem" yang berarti dikhususkan. Sebagian besar teks Alkitab dalam Ulangan dan Yosua, diasumsikan bahwa Allah menuntut kehancuran total dari musuh, contohnya Bil 21: 2-3; Ul 2:30-35; 7:2-6, dll. Akan tetapi Istilah herem sendiri juga dipakai untuk merujuk kepada hal pengorbanan dan penebusan yang diperuntukkan bagi para imam (Bil 18:14).

Banyak sarjana telah menunjukkan koneksi linguistik dan konseptual antara berbagai teks Alkitab dimana budaya bangsabangsa di sekitar daerah Timur Dekat Kuno pada waktu itu mengenai perang sebagai sesuatu yang diperintahkan oleh dewa dan setiap musuh yang ditaklukkan merupakan persembahan yang dikhususkan untuk dewa. Hal itu termasuk juga di Israel contohnya,

${ }^{6}$ Ensiklopedi Alkitab Masa Kini, Jilid 2 M-Z (Jakarta: YKBK, 1997) 238237. 
ketika bangsa Israel berperang melawan Kanaan mereka bersumpah kepada Allah akan menghancurkan semua kota-kota dan apa yang ada di dalamnya, dimana hal tersebut merupakan respon dari bantuan ilahi yang mereka terima (Bil 21:2-3). ${ }^{7}$

Kekerasan yang diperintahkan Allah di dalam Perjanjian Lama banyak menimbulkan masalah bagi para penafsir baik dari kalangan Yahudi maupun Kristen. Tradisi rabinik di kemudian hari pun mengungkapkan terpeliharanya kesukacitaan atas pembinasaaan orang-orang Mesir. Menurut tradisi umat Israel yang kemudian menyebutkan bahwa selagi para malaikat mulai memuji bersukacita, setelah pembebasan di Laut Merah, Allah berbicara kepada mereka: "Pekerjaan tangan-Ku telah mengeringkan laut, akan bernyanyikah kamu?" 8

Walter Brueggemann berpandangan dan memahami Yahweh sebagai prajurit ilahi di Isarel, secara umum dalam model perang yang adil: perang untuk mempertahankan dan melindungi kehidupan komunitas yang tertindas, yang berulang kali diancam oleh musuh yang lebih kuat. Brueggemann juga melihat aktivitas Allah yang berada di pingir batas kekerasan, bukan di pusatnya. Namun demikian, Brueggemann mengakui dimensi kekejaman lebih lanjut dalam gambaran Alkitabiah atas diri Yabweh sebagai prajurit. Di samping kekerasan terukur untuk mempertahankan keadilan mana pun, ada sesuatu yang aneh dan menakutkan: "sifat Yabweh yang terlihat kejam memperkenankan terjadinya kekerasan pada suatu kesempatan, yang tidak dapat diisi oleh makna keadilan mana pun.

${ }^{7}$ Niditch, War In The Hebrew Bible, A Study In The Ethics Of Violence, 27-32.

8 Ibid, 150. 
Kekerasan potensial tersebut dapat terjadi setiap saat, karena Yabweh pada akhirnya tidak bertanggung jawab kepada pihak lain, bahkan tidak pula kepada Israel sebagai umat-Nya".

Dengan bencana kekalahan Yosia, lembaga perang suci di Israel kuno mulai ditemukan ujungnya. Sebab hal itu pernah menjadi hancur sebelumnya yaitu, melalui cara-cara dimodifikasi dalam melancarkan perang di zaman raja-raja - tetapi pada saat yang sama muncul ideologi perang suci dalam tulisan setelah Salomo. Selanjutnya konsep perang suci mulai berkembang secara sangat independen dalam gerakan kenabian, kemudian kembali mengejutkan di bawah Yosia lembaga perang suci kembali keaslinya menjadi kelembagaan Sitz im Leben dan dari pengaturan bahwa sekali lagi memperoleh kekuatan baru dan dorongan. Lalu, perang suci sebagai lembaga sakral menjadi hancur oleh kekuatan militer pada tahun 608 SM, 596 SM, dan 587 SM. Konsep perang suci muncul kembali dalam bentuk teologis - yaitu, di Ulangan dan Deuteronomistis pengerjaan ulang dari literatur dan dalam narasi sejarah Tawarik. ${ }^{10}$

\section{Makna Perang Suci dalam Perjanjian Lama bagi Umat Israel}

Menurut Johnson dan Bainton keyakinan sebagian besar penulis Alkitab serta para pemikir diperiode awal modern dan klasik bahwa Allah telah memerintahkan perang atau bahwa firman Allah harus dipertahankan dengan cara berperang merupakan keyakinan yang

${ }^{9}$ Walter Brueggemann, Theology of the Old Testament: Testimony, Dispute, Advocacy (Minneapolis: Fortress, 1997) 250.

${ }^{10}$ von Rad, Holy War in Ancient Israel, 128. 
kurang tepat, sehingga batas antara perang yang adil dan perang suci menjadi kabur. ${ }^{11}$

Gerhard von Rad menjelaskan karakteristik utama dari perang adalah munculnya aliansi sakral yang komprehensif. Pada prinsipnya perang digambarkan sebagai respon dari kedua belas suku sebagai bentuk penyembahan kepada Yahweh, yang bukan hanya berperan sebagai dewa suku saja tetapi juga merupakan Allah "Israel". Selanjutnya, perang ini muncul sebenarnya sebagai suatu bentuk pertahanan dalam kasus ancaman perjanjian suku secara keseluruhan. ${ }^{12}$

Bangsa Israel menganggap bahwa perlakuan Allah terhadap mereka melalui sejarah adalah penyataan, sama seperti pesan yang disampaikan oleh seorang nabi Allah. Kuasa Allah ditekankan berulang-ulang dalam Kitab-kitab Yosua, Hakim-hakim dan Rut. Allah memberikan kemenangan kepada umat Israel atas bangsa Kanaan dalam menaklukkan negeri itu. Allah terus menyatakan diriNya sebagai Penguasa Tertinggi atas seluruh alam semesta. Seluruh bumi adalah milik-Nya (Yos 1:3; 14:1-2; $21 ; 43) .{ }^{13}$

Lagu atau nyanyian Debora dalam Hakim-Hakim 5 memahami peristiwa perang yang dialami oleh bangsa Israel sebagai perang suci: karena nyanyian itu berisi pujian kepada TUHAN, yang membuat tentara menjadi bersatu dan bersedia; Yabweh secara pribadi datang ke pertempuran; adanya intervensi dari surga, semua itu

${ }^{11}$ Niditch, War In The Hebrew Bible, A Study In The Etbics Of Violence, 26.

12 von Rad, Holy War in Ancient Israel, 65.

13 Roy B. Zuck (ed), A Biblical Theology of The Old Testament (Malang: Gandum Mas, 2005) 168-183. 
menunjukkan bahwa kejadian tersebut terjadi seperti di ruang sakral dan dalam bentuk sakral. ${ }^{14}$

Bagi Israel, perang dilakukan hanya sesuai dengan kehendak Allah, di bawah pimpinan-Nya, dan diselesaikan dengan kepercayaan kepada-Nya. Musuh Israel adalah musuh Allah. Kelangsungan hidup umat perjanjian milik Allah harus lestarai. Umat harus disucikan dari segala immoralitas yang hebat yang merusak kehidupan mereka, karena Israel menjadi alat penyelamatan ilahi bagi dunia. Hal tersebut membantu pengertian tentang larangan yang melibatkan pembinasaan tuntas (kherem) yang berarti dikhususkan untuk dimusnahkan (Yos 6:17). Di sisi lain, peperangan juga merupakan alat yang dipakai oleh Allah untuk menghukum bangsa Israel (Hab 1:6; Ye 10:5; Yer 25:1-9; Yeh 21:8-23). ${ }^{15}$

Peter C. Craigie berpendapat pemusnahan musuh baik pria, wanita, dan anak-anak-dengan cara apapun yang dianggap sebagai tindakan suci adalah tidak tepat, karena itu tidak lebih dari tindakan kultis dari asosiasi agama itu sendiri. Pandangan dunia dibentuk oleh normatif harapan teologis dari tradisi agama mereka sendiri (Oden). C.H.W. Brekelmans, misalnya, tidak menunjukkan bahwa kherem sebagai sarana untuk memperoleh bantuan Tuhan dalam perang itu dilakukan di awal perang secara khusus oleh Israel. Brekelmans menyebutkan bahwa hanya tiga teks Alkitab yang mengungkapkan ideologi "herem" ini (Bil 21:13; Josh 6-7; 1 Samuel 15) selebihnya itu berasal dari para pemimpin militer atau nabi, dan bukan dari Allah.

B.W. Anderson menjelaskan kherem sebagai hubungan antara larangan dan pengorbanan bagi Allah. Gagasan larangan sebagai

${ }^{14}$ von Rad, Holy War in Ancient Israel, 57.

${ }^{15}$ Ensiklopedi Alkitab Masa Kini, Jilid 2 M-Z, 238-237. 
kurban bukan satu-satunya model larangan yang ditemukan dalam Alkitab Ibrani, tapi kehadiran larangan sebagai kurban dalam Alkitab Ibrani tidak bisa ditolak. ${ }^{16}$

Pondasi ideologis agama dari perang suci, merupakan bagian dari suatu ritual primitif dari tradisi Israel kuno, sebagai bentuk praktik pemujaan yang ingin mengatur seluruh ruang kehidupan dalam masyarakat secara sakral dan terikat satu sama lainnya. Johannes Pedersen telah menggambarkan perang suci sebagai jaringan magis besar kekuasaan. Allah adalah sumber daya; dan dari Tuhan setiap prajurit secara individu menerima kekuasaan. Hal tersebut menunjukkan konsep iman dari Israel yang percaya diri dengan yakin pada tindakan Yahweh, dan hal itu menjadi ciri khas dari perang suci yang memiliki karakter dinamis dalam masyarakat Isarel kuno.

Perang suci bukanlah merupakan suatu perang agama atau dengan kata lain, dalam perang suci Israel tidak muncul untuk melindungi iman dalam Yahweh, tetapi TUHAN datang untuk membela Israel, karena Israel adalah milik Yahweh. Para pembaca dapat melihat bahwa penaklukan oleh suku-suku berlangsung dengan cara-cara damai. Di dalam perjalanan atau perkembangan sejarah selanjutnya dari perang suci ketika suku-suku mengalami kuasa Yahweh dalam bentuk sakral, itu adalah wahyu baru dari esensi perang suci tersebut. ${ }^{17}$

Martin Klingbeil menggambarkan Allah sebagai prajurit yang berjuang dari Surga dalam membela Israel dari musuh-musuhnya. 134.

${ }^{16}$ Niditch, War In The Hebrew Bible, A Study In The Ethics Of Violence, ${ }^{17}$ von Rad, Holy War in Ancient Israel, 69-73. 
Dalam Mazmur 18: 8-16, diriwayatkan acara theophanic(penampakan diri Allab) dimana Yabweb turun dari Surga dan fenomena ini dijelaskan dalam hal fenomena alam. Spasial yang dimensi dari atas ke bawah. Hanya dalam bagian ini dari seluruh Alkitab Ibrani terlihat bahwa Yahweh naik kerub, seperti layaknya seorang raja pada kereta perang.

Contoh lain adalah Mazmur 29, yang terkenal untuk repetisi dari "suara Yahweb" sebagai suara badai. Klingbeil menganggap Mazmur ini sebagai deskripsi dari metafora seorang prajurit. Dan di sini, prajurit ini menaklukkan wilayah. Gambaran spasial dari mazmur ini relevan untuk pemahaman ini: dari Mediterania, menuju Gunung Lebanon, Gunung Hermon, dan gurun Kades. Yabweb berasal dari perairan, menaklukkan kekacauan, dan mendominasi pedalaman dan menggunakan gunung sebagai bukti kekuasaan-Nya. ${ }^{18}$ Klingbeil berpandangan bahwa Allah sebagai prajurit memiliki kuasa yang lebih tinggi dan dapat menghancurkan kekuatan dewa-dewa sesembahan penduduk daerah Timur Dekat Kuno, baik itu secara langsung maupun melalui fenomena-fenomena alam. Dampaknya adalah umat Israel hanya berperan sebagai penonton dan bukan sebagai objek yang terlibat di dalamnya, karena Allah sendiri yang berkerja untuk menghancurkan musuh-musuh Israel. Umat Israel diajar untuk percaya dan yakin dengan iman terhadap pertolongan Yahweh.

${ }^{18}$ Martin Klingbeil, Yahweb Fighting from Heaven, God as Warrior and as God of Heaven in the Hebrew Psalter and Ancient Near Eastern Iconography (Switzerland: University Press Freiburg Vandenhoeck \& Ruprecht Göttingen, 1999) 38-152. 
Bagi Israel, fitur yang paling penting dari perang suci adalah permintaan iman dalam tindakan penyelamatan yang dilakukan oleh Yahweh. Namun, von Rad berpendapat, itu bukanlah Yahweh sendiri yang bertindak; akan tetapi orang Israel percaya bahwa Yahweh hadir dan menyertai dalam pertempuran yang mereka lakukan dan memberikan kemenangan kepada mereka. ${ }^{19}$

\section{Implikasi dari Perang Suci dalam Perjanjian Lama Bagi Kehidupan Iman Orang Percaya Saat Ini}

Pendekatan kritis lain secara langsung terhadap ideologi perang suci dikemukakan oleh Martin Buber, yang memberikan ulasan terhadap permintaan nabi Samuel, atas nama Allah, agar Saul tidak hanya membunuh pimpinan bangsa Amalek yang tertangkap, namun semua bangsa Amalek, termasuk bayi dan anak-anak (1 Sam 15:3). Buber menegaskan bahwa Samuel sudah salah dalam memahami Allah. Bagi buber dari kesaksian Alkitab timbul suatu pemahaman tentang Allah yang membentuk penilaian orang-orang percaya. ${ }^{20}$

Ajaran Kristen mengenai perang dan damai akhir-akhir ini, sering menolak secara implisit tuntutan Musa, Yosua dan Samuel yang keras untuk suatu perang suci, tanpa merefleksikan secara eksplisit berbagai asumsi atau implikasi dari penolakan terhadap ajaran Alkitab. Contohnya, diskusi mengenai perang nuklir dalam surat pastoral uskup-uskup Katolik Amerika, penegasan Paus

${ }^{19}$ von Rad, Holy War in Ancient Israel, 40.

${ }^{20}$ Martin Buber "Autobiographical Fragments," dalam The Philosophy of Martin Buber, peny. Paul Arthur Schilp (LaSalle, Illionis: Open Court, 1967) 32. 
Yohanes Paulus II mengenai kekudusan hidup semua manusia, secara sembunyi-sembunyi mengabaikan tuntutan alkitabiah untuk membinasakan total semua lawan Isarel. Teks Alkitab yang menjelaskan mengenai permintaan Samuel untuk membunuh semua bayi-bayi orang Amalek atas nama Allah (1 Sam 15:3), seakan-akan bertentangan dengan ajaran dari Tuhan Yesus dan pernyataan Paus Yohanes Paulus II yang mengajarkan tentang kasih, baik kepada Allah maupun kepada sesama manusia. Namun, sebagian orang Kristen dan Yahudi saat ini, dalam praktiknya lebih banyak memilih perspektif Alkitab sebagai penyataan kehendak Allah dan dengan diam-diam menolak yang lain. Memilih Allah di atas Alkitab merupakan tantangan terbesar bagi umat Yahudi dan Kristen saat ini. ${ }^{21}$

Implikasi langsung dari perang suci dalam Alkitab bagi kehidupan iman orang percaya saat ini adalah adanya sebagian kelompok tertentu yang memegang pemahaman bahwa perang demi membela agama dan Tuhan dapat dibenarkan. Perang atas nama Allah atau agama juga menjadi akar konflik yang berkepanjangan, seperti yang terjadi di Timur Tengah hingga saat ini. Lebih lanjut lagi akibat perang juga menimbulkan luka fisik dan mental diantara kedua belah pihak. Akibat yang lebih parah adalah banyaknya orang yang tidak lagi mempercayai intitusi agama, bahkan bersikap skeptis terhadap kekristenan, dan meninggalkan Tuhan, seperti yang terjadi di negara-negara Eropa. Hal tersebut dimulai sejak awal Masa Pencerahan, di mana dunia Barat telah berupaya untuk membebaskan diri dari setiap gagasan yang berhubungan dengan

${ }^{21}$ Lefebure, Penyataan Allah, Agama, dan kekerasan, 96. 
ilahi. Di mana Tuhan dari agama Yahudi dan Tuhan agama Kristen telah diturunkan sebagai sosok masa lalu dan menjadi masyarakat ateis sekuler yang ada saat ini.

Dampak lain juga terjadi kepada gereja. Gereja telah mengobarkan semangat perang dalam diri umat Kristen pada masa lampau, bahkan gereja sebagai suatu lembaga institusi agama dengan kekuasaan dan pengaruhnya telah melegalkan perang atas nama Tuhan. Akibatnya terjadi beberapa kali Perang Salib yang berkepanjangan, dan memakan banyak kurban jiwa dan harta benda, baik itu dari pihak kristen, Islam, maupun Yahudi, dan diakhiri dengan kekalahan dari pihak Kristen. Akibatnya, hingga saat ini, gereja selalu dibenci dan menjadi sasaran dalam kekerasan di negaranegara Islam, semua itu disebabkan oleh karena luka batin yang ditimbulkan dari Perang Salib pada masa lampau.

\section{PENUTUP}

Semua perilaku perang dalam Perjanjian Lama terjadi bersamaan dengan munculnya kebudayaan manusia itu sendiri. Perilaku perang merupakan masalah yang kompleks dan susah untuk dimengerti, karena selalu ditemukan di dalam setiap kebudayaan suatu bangsa atas alasannya masing-masing. Adanya pandangan mengenai Ideologi perang sebagai perintah Allah menurut Susan Niditch, tidaklah tepat karena teks-teks yang ada mengenai perang saling berkontradiksi. Berkaitan dengan ideologi perang yang terdapat di dalam Perjanjian Lama setidaknya ada tujuh ideologi yang menjadi tradisi dari Israel kuno, dimana ideologi tersebut masing-masing memiliki fungsi dan aturan tersendiri di dalam sejarah Israel. Namun satu hal yang perlu digaris bawahi mengenai tradisi perang dalam 
Perjanjian Lama adalah masalah itu berkutat disekitar persoalan kasih sayang dan permusuhan. Budaya perang yang terjadi di dalam Perjanjian Lama telah mempengaruhi perjalanan sejarah sosial dan intelektual bangsa Israel itu sendiri.

Perang Suci pada awalnya merupakan suatu lembaga sakral yang terbentuk sebagai perjanjian antara Israel dengan Allah dengan tujuan untuk menjaga iman mereka dari gangguan pihak luar.Di dalam perkembangannya perang suci telah mengalami perubahan bentuk dan fungsi. Sebagai contoh yaitu, perang yang tadinya dilakukan karena pembelaan iman, menjadi perang karena motif politik dan militer. Sehingga perang tersebut tidak lagi bisa disebut sebagai perang suci, karena perang itu tidak disakralkan terlebih dahulu melalui ritual keagamaan. Selain itu, perang tersebut pun dilakukan oleh tentara profesional dengan motif ekonomi yang utama, dan bukan oleh rakyat jelata yang dengan kesadaraannya mengabdikan dirinya dalam perang demi mempertahankan perjanjian iman dengan Allah.

Pada prinsipnya tidak ada perang suci, karena di dalam setiap perang yang terjadi selalu terselip keinginan pribadi atau hawa nafsu duniawi dari setiap pelaku perang itu sendiri. Disebut perang suci, karena adanya campur tangan Allah di dalamnya yang bertujuan untuk menjaga kemurnian dari perjanjian yang telah Allah buat dengan manusia. Lebih lanjut, tidak semua perang yang terjadi di dalam Perjanjjian Lama karena Allah yang memerintahkan. Di dalam mempelajari perang ini pun setiap orang harus benar-benar teliti, sebab teks yang satu dengan yang lainnya kadang berbeda makna utamanya. Craigie sendiri pernah mengungkapkan bahwa menerima historisitas narasi perang dalam Perjanian Lama sekalipun disadari 
tidak mudah menjelaskannya. Yang menarik, Craigie melihat perangperang dalam Perjanjian Lama dalam bingkai seluruh pewartaan Alkitab. Sekalipun Allah nyata terlibat dalam perang-perang Israel, Israel tetap sebagai sebuah bangsa yang terdiri atas orang-orang berdosa dan institusi pemerintahannya bersifat duniawi, termasuk memakai perang sebagai cara mempertahankan eksistensinya. Menurutnya, perang murni berasal dari hawa nafsu manusia (Yak. $4: 1, \mathrm{NKJV}){ }^{22}$

Robi Prianto, menyelesaikan pendidikan Sarjana Teologi dari ST'T SAPPI, dan saat ini sedang dalam tahap akhir untuk jenjang S2 (M.Th.) dari ST'T Cipanas. Sekarang sebagai dosen tetap di STT SAPPI, Cianjur.

22 Peter C. Craigie dalam Yongky Karman, Perang dalam Perjanjian Lama: Problem Reinterprestasi. http://www.alkitab.or.id/biblika/Yonky4.htm. Diunduh pada tanggal 13 Januari 2015. 